\title{
HISTORICAL CLASSIFICATION AND EFFICIENCY OF THE SUPERVISORY SYSTEM OF INTERNATIONAL LABOR ORGANIZATION
}

\author{
HUSEYIN SEVGI \\ Department of Labor Economics and Industrial Relations, Kirklareli University, Turkey. Email: hsevgi@gmail.com
}

Received: 20 January 2021, Revised and Accepted: 19 February 2021

\section{ABSTRACT}

Objective: International Labor Organization (ILO) has established some supervisory systems to check the extent to which its decisions are implemented. With these supervisory systems, the organization tries to determine to what extent its decisions are implemented by the member countries. In this context, this study aims to classify the types of ILO supervisory systems and to analyze how they work and how effective they are.

Methods: This study is based on a systematic literature review. Rather than the traditional literature review, a systematic literature review implies that efficient, systematic, and reproducible methods to identify, evaluate, and synthesize existing literature. As the basis of the literature review, ScienceDirect databases have been selected. 239 research articles and 23 book chapters were analyzed.

Results: When we examine the supervisory mechanisms in the ILO, one point should be emphasized to fully grasp the topic as a whole and to define the impact of the organization in today's global capitalist system: ILO is an international organization with no concrete sanction power despite its many supervisory systems.

Conclusions: The main reason for the lack of sanction tools in the ILO's control system lies in its ideological background. As a representative of the reformist ideology, the ILO aims to impose its rules on the states by "persuasion method" as required by this ideology.

Keywords: International labor organization, International social policy, Supervisory system.

(C) 2021 The Authors. Published by Innovare Academic Sciences Pvt Ltd. This is an open access article under the CC BY license (http://creativecommons.org/ licenses/by/4.0/) DOI: http://dx.doi.org/10.22159/ijss.2021v9i2.40843. Journal homepage: https://innovareacademics.in/journals/index.php/ijss

\section{INTRODUCTION}

International Labor Organization (ILO) is among the top actors of the international social policy. Moreover, there are certain parallels between the historical development of the idea of international social policy and the intellectual foundations of ILO. Based on this context, we can divide the factors affecting the historical development of international social policy into two fundamental groups: Personal efforts and official efforts. Moreover, we cannot address one factor without mentioning the other Historically, they have taken place simultaneously and intersected at different times. Therefore, these efforts must be regarded and addressed as parts of a whole to fully grasp the historical development of international social policy [1].

Personal efforts refer to the initiatives of business people and the clergy of the period who act with the sense of "philanthropy." These people generally witness the havoc wreaked by the undesirable working and living conditions on people and strive to correct them. The efforts of these people have, over time, become common with official efforts [2,3].

The first meetings organized by personal efforts were made under the name of the "International Charity Congress" in 1856 and 1857. The people attending the congresses, most of whom were clergymen, discussed the regulations required for the labor conditions, most of which stemmed from religious feelings. Mainly organized by Edouard Ducpétiaux from Belgium, the congresses revolved around the opinions on protecting workers through international regulations instead of antisystem criticism. Robert Owen and Daniel Legrand were the ones who had made the most important personal efforts on international social policy. Owen and Legrand are, for this reason, quite important for the historical development of ILO. ILO emphasizes that the discussions on the necessity of an international organization on the working life issues started under the leadership of Robert Owen and Daniel Legrand $[4,5]$.
Owen emphasized that workers were employed as a slave with very low wages and long hours, the conditions were not sustainable, and if the necessary precautions were not taken in time, it could have consequences that could lead the whole British economy to bankruptcy in a short time. What makes Owen important in terms of international social policy is that he wrote letters to the notable politicians and heads of state of the period about his experiences in social policies he implemented in his factories. Daniel Legrand also took an important step in international social policy by systematically and decisively developing the idea of making international regulations on social policy. Legrand conveyed his views on international social policy to the governments of Germany, England, Russia, and France and proposed the establishment of an institution to determine international labor norms $[6,7]$.

The contribution of the Fabian Community and the people in it is also quite high in the development of international social policy thought. A middleclass intellectual movement, Fabian Society argued that the social order could be improved by politics, not by conflict. According to the society, a fairer and more democratic social order would be achieved with the development and evolution of capitalism. The disorders of the capitalist order can be prevented by collective bargaining, cooperatives, and social policies [8]. Marx criticized this community saying, "Utopian socialists advocate an interventionist ideology that can be called Reformist today. Those who are in this opinion do not offer a socialist solution proposal, even though their perspective for solving the problems is well-intentioned $[9,10] . "$

The historical development of international social policies started with personal efforts and it was made more concrete with official efforts. Official efforts refer to the bureaucratic efforts of states and all international initiatives of the working class. In this context, the most important international efforts of the working class for the international social policy were the First International and the Second International. The First International is the first mass organization that 
aims to bring together workers from different countries for common purposes. Different radical and leftist political tendencies in Europe all found a place in the International. The first attempts from the working class to solve the issues of the existing system revolved mostly around Marxism and aimed to change the system completely. In this context, the establishment of the First International was quite an important example for all workers both at the international level and for Marxism [11,12].

The Second International was a milestone event, the birthplace of many decisions that are still relevant today just like the International Workers' Day and International Women's Day. The Organization also ran campaigns to limit the daily working hours to $8 \mathrm{~h}$. However, the approaching First World War turned out to be a severe obstacle for the organization. The strict nationalistic policies of the states limited the activity area of the Second International and the organization had to dissolve in 1914 due to the impact of the First World War [13,14].

As the First World War continued, the idea of creating an international social policy was kept alive with some official efforts. Leeds Conference in 1916, Stockholm and Bern Conferences in 1917, two London Conferences in 1918, Bern Conference and Amsterdam Conference in 1919 were among the examples of these efforts. Although the scope of these conferences was different, their common goal was to found an organization to establish international labor standards. Along with the end of World War I, it was decided to formally establish the ILO in 1919 with the articles added to the Treaty of Versailles under the political conjuncture of the period (Fig. 1) [15].

\section{METHODS}

In any research project that requires a transparent approach, mapping, and evaluating the literature in a specific field is a key objective. This study is based on a systematic literature review. Rather than the traditional literature review, a systematic literature review implies that efficient, systematic, and reproducible methods to identify, evaluate, and synthesize existing literature [16]. The process of the systematic literature review can be divided into seven steps: Defining the research question, choosing the databases, selecting the search terms, applying practical screening, applying methodological screening, doing the review, and synthesizing the results [17].

For structuring the literature review and addressing the aim of this study, the following research questions are:

RQ1: How was the ILO's supervisory system formed, classified, and developed?

RQ2: How effective is ILO's supervisory system on the implementation of conventions and recommendations?

The research questions are aiming at to classification of ILO's supervisory system and establish a link between the ideological background of ILO and the supervisory system. As the basis of the literature review, ScienceDirect databases have been selected. ScienceDirect includes more than 4.300 peer-reviewed, high-quality journals, and 30.000 books from all over the world and different disciplines and which should therefore cover the most important publications in the field. The review includes every empirical and conceptual journal paper written in English. Book reviews, editorial notes, and comments were excluded in the study.

The relevant keywords for the research question have to be identified. Since the research question aiming at "user labor" these keywords were preferred in searches:

"ILO" OR "International Labor Organization" OR "Supervisory System" OR "International Social Policy" OR "produsage" AND "labor exploitation"

To increase search output quality is limited the search to title, abstract, and subject terms. To limit the search results to related topics, only research articles and book chapters in the field of social sciences are included in the search. The time frame is limited from 1990 to 2020 [18].

The initial search resulted in 239 research articles and 23 book chapters identified. To further focus search and ensure a high quality of the results these unrelated publication titles were excluded: "Tourism Management," "Geoforum," "Journal of Rural Studies," "Computers and Composition," "Journal of Rural Studies," and "Environmental Innovation and Societal Transitions." With these selection criteria, results were only 142 research articles. Afterward, it is applied to an article-by-article quality screening process to determine the fit of the remaining 58 search results with the objectives of the literature review. In a subsequent step, each categorized the 58 articles according to these important aspects: Dimensions of ILO's supervisory system, classification of supervisory system, history of ILO, social policy, and international social policy.

\section{RESULTS}

ILO's efforts to create international rules for the working life, with its conventions and recommendations, also brought along the supervisory systems as their natural result and necessity. ILO established certain supervisory mechanisms to check to what extent its rules are implemented by states. When we examine the supervisory mechanisms in the ILO, one point should be emphasized to fully grasp the topic as a whole and to define the impact of the organization in today's global capitalist system: ILO is an international organization with no concrete sanction power despite its many supervisory systems.

ILO has been trying to update its supervisory system and fill the gaps in parallel with the changing political and economic conditions since its establishment. Even though all these efforts had fundamentally good intentions to ensure the implementation of conventions, they failed to change the basis of the supervisory system as a requirement of the reformist ideology. The concept of "persuasion" lies at the heart of ILO supervisory systems.

The supervisory systems established by the ILO have been shaped according to the changing conditions over time, just like the organization itself. With new conditions brought by each period, both the content and scope of supervisory systems have expanded. Since its establishment, the supervisory systems in ILO are divided into two main parts as Regular Supervisory and Specific Supervisory.

The efforts to improve international labor standards are supported by a unique international supervisory system. ILO examines labor standards in member countries with the conventions it approves and strives for the effective implementation of the conventions in member countries. If the organization detects problems in the implementation of the convention in any country through its supervisory system, it tries to form bases for the implementation of the convention by helping the country with social dialogue and technical aid activities.

Regular supervisory can be conducted with the approval condition in two different ways. The first is the periodic (annual) reports sent each year by member states between June 1 and September 1 . The second step of the regular supervisory is conducted on complaints from state parties, the delegates of the International Labor Conference, or union organizations. Therefore, by signing any convention, a state assumes legal responsibility not only to the ILO but also to other state parties and other social partners. This is the natural outcome of ILO's tripartite principle.

For the "Reports Supervisory," provided by regular annual reports, Article 22 of the ILO Constitution was amended as "Each Member State undertakes to submit an annual report to the International Labor Organization containing the measures it has taken to implement the conventions it has acceded to. These reports will be written as specified by the Governing Body and contain the express information it demands." 
Responsibilities of member states regarding reports supervisory are not limited to sending annual reports. When a member state ratifies any ILO convention, it is also responsible for sending regular reports on the measures taken to implement the convention in its country. Besides, the governments have to submit a detailed report including the legal and practical steps they have taken on ILO's eight fundamental conventions and four priority conventions every 2 years. The ILO also has the right to request reports on the implementation of the conventions at shorter intervals. Labor and employer organizations can comment on reports submitted by their governments and submit their reports on the implementation of conventions [19].

Two different commissions were established in 1926 to ensure the regular supervision of member states with annual reports. The first of these is "the Committee of Experts on the Application of Conventions and Recommendations," also known shortly as the "Committee of Experts." The second committee is "the Committee of Conference on the Application of Conventions and Recommendations" and it is also known as the "Committee of Conference." These two committees have remained the cornerstones of the ILO supervisory system, even though their supervisory systems have differentiated over time.

The Committee of Experts is one of the exceptions to the tripartite principle under the ILO. This committee consists of lawyers working on the principle of independence and who are appointed by the ILO Governing Body. Committee members are selected from different geographical regions, different legal systems, and different cultures. The committee meets each year in November and December and prepares reports with three main sections. These are "General Report," "Observations concerning particular countries," and "General Survey." The Committee of Experts makes two types of comments when examining the practice of international labor standards. These are "Observations" and "Direct Requests." Observations include comments made by a member state on the main issues related to the implementation of a particular convention. These observations are then published in the annual report of the Committee. Direct requests, on the other hand, cover more technical issues and contain the requests made by the committee to the relevant country to learn more about an issue. These requests are not included in the reports but sent directly to the concerning governments [15].

The task of the Committee of Experts is described by the committee in the report submitted to the $63^{\text {rd }}$ International Labor Conference as follows: "The function of the committee is to determine whether the requirements of a given Convention are being met, whatever the economic and social conditions existing in a given country. These rules are uniform for all countries. The only exception to that is the one recognized by the convention. The Committee is only guided by the rules of the convention in its supervisory activities. However, modes of their implementation may be different in different states. The implementation of international rules is uniform. It should not be affected by any approaches stemming from any social or economic system [20]."

The Committee of Conference, on the other hand, is the second important pillar of the Reports Supervisory and consists of employer, worker, and government representatives, complying with the tripartite principle. A permanent committee in the International Labor Conference, the Committee of Conference meets each year in June during the International Labor Conference. The committee examines the information provided by the member states on the measures they have taken and the results of the supervisions to conduct the conventions they are a party to, the reports sent by the states, the information, and measures. It also examines the cases added in the special observations of the Committee of Experts [19].

The second supervisory method implemented in the regular supervisory mechanism is the complaint supervisory. Inspired by judicial methods, but not judicial itself, the complaint supervisory is divided into two according to the source of the complaint claiming that an approved convention is not implemented sufficiently. These are "union complaints" and the "state or conference delegate complaints."

Article 24 of the ILO Constitution was regulated as, "In the event of any representation being made to the International Labor Office by an industrial association of employers or workers that any of the Members has failed to secure in any respect the effective observance within its jurisdiction of any Convention to which it is a party, the Governing Body may communicate this representation to the government against which it is made, and may invite that government to make such statement on the subject as it may think fit."

On submitting any complaint to the Commission of Inquiry Commission according to Article 26 of the ILO Constitution, each member state, whether directly related to the complaint or not, can submit any information it holds to the commission. The commission then prepares a report after examining the complaint in detail. The commission states its findings on all matters that allow the scope of the objection to be determined, the measures to be taken to inform the complaining government, and its recommendations on the time limits for taking these measures. Then, the General Director of the International Labor Office sends the report of the Commission of Inquiry to the Governing Body and each of the governments involved in the dispute and publishes the report. Each of the concerning governments notifies the DirectorGeneral of the International Labor Office within three months whether they accept the recommendations in the Committee report and, if they do not, whether they want to take the dispute to the International Court of Justice. If the complaint is submitted to the International Court of Justice, the decision of the International Court of Justice cannot be rejected [21]

The last stage of completing the supervisory system in ILO is specific supervisory. The main reason for the need for specific supervisory along with the regular supervisory is the narrow scope of the general supervisory system. Within the scope of the regular supervisory, the precondition for the operation of both reports supervisory and complaint supervisory is the approval of the relevant convention. In other words, to have one of these supervisory systems, states must be both a member of the ILO and have ratified the relevant convention. Otherwise, the system does not work. In this case, states that do not sign a convention remain outside the supervisory system. In this respect, the narrow scope has led to the need for a different supervisory system.

The first body established to ensure specific supervisory was the "the Fact-Finding and Conciliation Commissions on Freedom of Association" by the ILO Governing Body in 1950 as a result of the negotiations with the United Nations Economic and Social Council. This Commission consists of nine independent persons. The main task of the committee is to investigate the complaints on the violation of the principles of freedom of association. Another body of the specific supervisory is the "Committee on Freedom of Association." This committee consists of the worker, employer, and government representatives by the tripartite principle. It was founded in 1951 by the ILO Governing Body. Like the Governing Body, it meets 3 times a year in March, June, and November. It examines the alleged violations and complaints on the freedom of association. It conducts the necessary research on this issue regardless

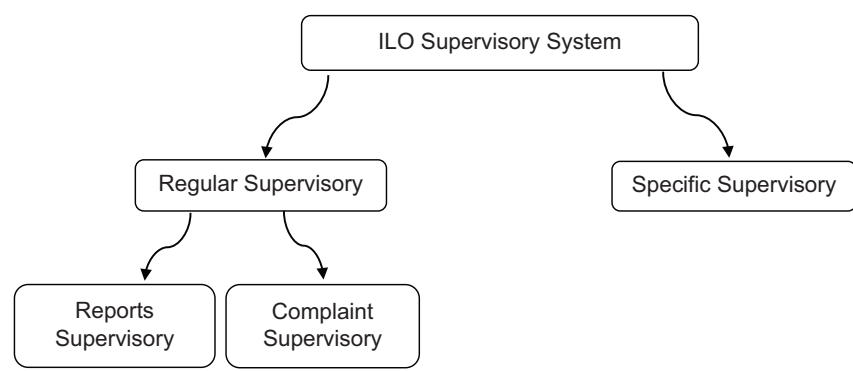

Fig. 1: International labor organization supervisory system 
of whether the relevant state ratifies the conventions. It investigates the severity of claims and whether it is worth submitting to the Governing Body. It works as a preliminary investigation committee [22].

\section{CONCLUSIONS}

The ILO strives to achieve its aim to create international labor standards through conventions, recommendations, and declarations. However, the ideology and the dynamics of the organization may contradict its "rulemaking" goal. Two factors underlie the power of "rule-making" on any subject. These are the supervision of the established rule and the imposition of certain sanctions if the rule is not implemented. If there is no sanction for the violation of the rules, the rules created will not be more than words on a piece of paper. In this context, the ILO establishes rules on the working life and establishes a supervisory system to determine whether these rules are implemented or not. However, the ILO's supervisory system does not prescribe any sanctions for states that do not comply with the rules. Supervision is based on continuous dialogue, cooperation, and persuasion with states to ensure they fulfill their obligations arising from the conventions they ratify or they have assumed as member states.

ILO's supervisory system, which claims to make rules at an international level, is its weakest point that should be the strongest. The supervisory system is not only the weak point of the ILO, but it also conflicts with the mission imposed on the ILO. It is not a coincidence that the ILO, which undertakes the extremely important task of establishing international rules on the working life, does not have concrete sanction power against states that can disregard its rules. Even if the ILO establishes an important convention on the working life, if any of the member states do not ratify this convention, the only thing it can do is to request a report from that state. It was stated in Article 19 of the ILO Constitution as follows: "If the Member does not obtain the consent of the authority or authorities within whose competence the matter lies, no further obligation shall rest on the Member except that it shall report to the Director-General of the International Labor Office, at appropriate intervals as requested by the Governing Body, the position of its law and practice concerning the matters dealt with in the Convention, showing the extent to which effect has been given, or is proposed to be given, to any of the provisions of the Convention by legislation, administrative action, collective agreement or otherwise, and stating the difficulties which prevent or delay the ratification of such convention [15]."

The main reason for the lack of sanction tools in the ILO's control system lies in its ideological background. As a representative of the reformist ideology, the ILO aims to impose its rules on the states by "persuasion method" as required by this ideology. In this context, the prerequisite for the ILO to continue its activities depends on not leaving states in a difficult situation and not having problems with the dynamics of capitalism. For this reason, the ILO cannot force countries to implement any of its rules through sanctions.

\section{REFERENCES}

1. Deacon B, Hulse M, Stubbs P. Global Social Policy: International Organizations and the Future of Welfare. California: Sage Publications; 1997.

2. Commercial International Bank. Congres International De Bienfaisance De Bruxelles. Montana: Kessinger Publishing; 2010.

3. International Labor Organization. Report of the Committee of Experts on the Application of Conventions and Recommendations. Geneva: International Labour Office; 2020.

4. Claeys G. Non-Marxian Socialism. In: Gareth SJ, Gregory C, editors. The Cambridge History of Nineteenth-Century Political Thought. Cambridge: Cambridge University Press; 2011. p. 521-55.

5. O'Hagan FJ. Robert Owen and Education. In: Noel T, Chris W, editors. Robert Owen and His Legacy. Wales: University of Wales Press; 2011. p. 71-91.

6. Meyer WH. Testing theories of labor rights and development. J Hum Right Quar 2015;37 Suppl 2:414-38.

7. Available from: https://www.fabians.org.uk/about-us/our-history. [Last accessed on 2021 Jan 09].

8. David WL. Socialism, Utopianism and the Utopian Socialists. J His Euro Idea 1992;14 Suppl 2:185-201.

9. Marx K. The Communist Manifesto. London: Pluto Press; 1996. p. 1818-83.

10. Available from: https://www.marxists.org/archive/steklov/history-firstinternational/index.htm. [Last accessed on $2021 \mathrm{Jan}$ 02].

11. Yorke O. Secret History of the International Working Men's Association, London: Bibliolife Publishing; 2008.

12. Duclos J. The First International. Istanbul: Sorun Publishing; 1969.

13. Joll J. The Second International 1889-1914. New York: Harper and Row; 1966.

14. Geary D. The second international: Socialism and social democracy. In: Terence B, Richard B, editors. The Cambridge History of TwentiethCentury Political Thought. Cambridge: Cambridge University Press; 2003. p. 217-38.

15. Available from: http://www.ilo.org/global/about-the-ilo/history/langen/index.htm. [Last accessed 2020 Dec 24].

16. Fink A. Conducting Research Literature Reviews: From the İnternet to Paper. Los Angales: Sage Paplications; 2020.

17. Massaro M, Dumay J, Guthrie J. On the shoulder of giants: Undertaking a structured literature review in accounting. J Account Audit 2016;29 Suppl 5:767-801.

18. Torres L, Royo S, Garcia-Rayado J. Social media adoption by audit institutions a comparative analysis of Europe and the United States. J Gov Inf 2020;37 Suppl 1:1-14.

19. International Labor Organization. Handbook of Procedures Relating To International Labour Conventions and Recommendations. Geneva: International Labour Office; 2019.

20. International Labor Organization. International Labour Conference $63^{\text {rd }}$ Session Report III. Geneva: International Labour Office; 1977.

21. International Labor Organization. Constitution of The International Labour Organisation and Selected Texts. Geneva: International Labour Office; 2010.

22. Tajgman D, Curtis K. Freedom of association: A user's guide. In: Standards, Principles and Procedures of the International Labour Organization. Geneva: International Labour Office; 2000. 